\section{Plastics that made history - the contribution of conservation science for the history of the Portuguese Plastics Industry}

\section{Plásticos que fizeram história - a contribuição das ciências da conservação para a história da Indústria Portuguesa dos Plásticos}

\author{
SUSANA FRANÇA DE \\ SÁ ${ }^{1 *}$ (i) \\ SARA MARQUES DA \\ CRUZ $^{2}$ \\ MARIA ELVIRA \\ CALLAPEZ ${ }^{2}$ \\ VÂNIA CARVALHO ${ }^{3}$
}

1. Department of Conservation and Restoration and LAQVREQUIMTE, Faculty of Science and Technology, Universidade NOVA de Lisboa, Caparica Portugal

2. Centro Interuniversitário de História das Ciências e da Tecnologia, Faculdade de Ciências, Universidade de Lisboa, Lisboa, Portugal 3. Museu de Leiria, Câmara Municipal de Leiria, Leiria, Portugal

"susana.sa@fct.unl.pt

\section{KEYWORDS}

Historical plastics Portuguese Industry History of technology Infrared spectroscopy Conservation and restoration

\title{
Resumo
}

Os objectos em plástico do nosso património cultural constituem testemunhos materiais da nossa história, tecnologia e indústria. Ainda assim, em Portugal, não existe o museu dos plásticos e as colecções existentes estão dispersas por coleccionadores particulares e unidades fabris. O projecto de investigação, "O Triunfo da Baquelite - Contributos para uma história dos Plásticos em Portugal", pretende construir esse museu. Para tal, o trabalho de investigação deu lugar à exposição, "Plasticidade - Uma História dos Plásticos em Portugal", no Museu de Leiria, em 2019. Este estudo apresenta o contributo das ciências da conservação na escrita desta história e na preparação de cerca de 150 objectos históricos em plástico para a exposição. Baquelite, melamina, polietileno, polipropileno, poliestireno e policloreto de vinilo plastificado são apenas alguns exemplos dos polímeros identificados por espectroscopia de infravermelho. Esta identificação foi essencial para contar a história da indústria dos plásticos em Portugal. Os espectros e as bandas de absorção características de cada polímero são apresentados.

\section{PALAVRAS-CHAVE}

Plásticos históricos Indústria Portuguesa História da tecnologia Espectroscopia de infravermelho Conservação e restauro 


\section{Introduction}

There is no doubt that "plastics are fascinating materials which have invaded every aspect of modern living" [1]. Polyamide, polyethylene, poly(methyl metacrylate), polystyrene, poly(vinyl chloride) and polyurethane are only some examples of "poly" materials that we can easily find in our daily life objects. The triumph of plastics in the last century has been unquestionable, especially since the $1960 \mathrm{~s}$ where plastics chiefly became popular in art, fashion, design and daily life. Accordingly, we can look at plastic objects as important witnesses to our time. Unfortunately, the Portuguese panorama on the history of plastics is still poorly known. With the attempt to contradict this lack of knowledge, the research work developed by Maria Elvira Callapez has been crucial. From her research into documentary sources on the Portuguese plastics industry, the titles, Os Plásticos em Portugal [2] and História do PVC em Portugal [3] were published, gathering and producing precious information on this subject. Also, since 2016, the funded research project, "The Triumph of Bakelite - Contributions to a History of Plastics in Portugal" (PTDC/IVC-HFC/5174/2014), has been focusing on the national plastics history with an interdisciplinary approach that brings together the historical, technological and social perspectives of this modern material. The collection of both documentary and oral sources, along with the thorough study of historical objects were carried out, with the final goal of contributing to a more complete history of the Portuguese plastics industry. The project includes a vast team of experts from different areas of knowledge (such as historians, chemists, engineers, conservators, museologists and anthropologists), aiming at looking at plastics as material cultural testimonies. Based on the research work developed so far, the exhibition "Plasticity - A History of Plastics in Portugal" has been planned (Figure 1) and already on display since April 6, 2019, at Museu de Leiria, Portugal. The exhibition aims at valuing the importance of the plastics heritage in the country. Circa one hundred and fifty plastic objects from private collections, industries, museums and academic institutions/research centres have been selected for display, including objects covering the main ages of the Portuguese plastics" industry (1930s-2000s) and plastic formulations - thermosetting polymers such as formaldehyde resins; and thermoplastic polymers such as polyethylene (PE), polypropylene (PP), polystyrene (PS), poly(methyl methacrylate) (PMMA) and plasticized poly(vinyl chloride) (PVC), among others. However, the selected historical plastic objects were not prepared to be exhibited (not identified nor cleaned), thus molecular characterisation was crucial to: i) accurately identify the objects on display, ii) select the best conservation and restoration procedures, and iii) to enrich the writing of the Portuguese plastic history. As known, thousands of different polymers can be used to produce a plastic, and beyond this fact, plasticisers, stabilisers, colorants, fillers

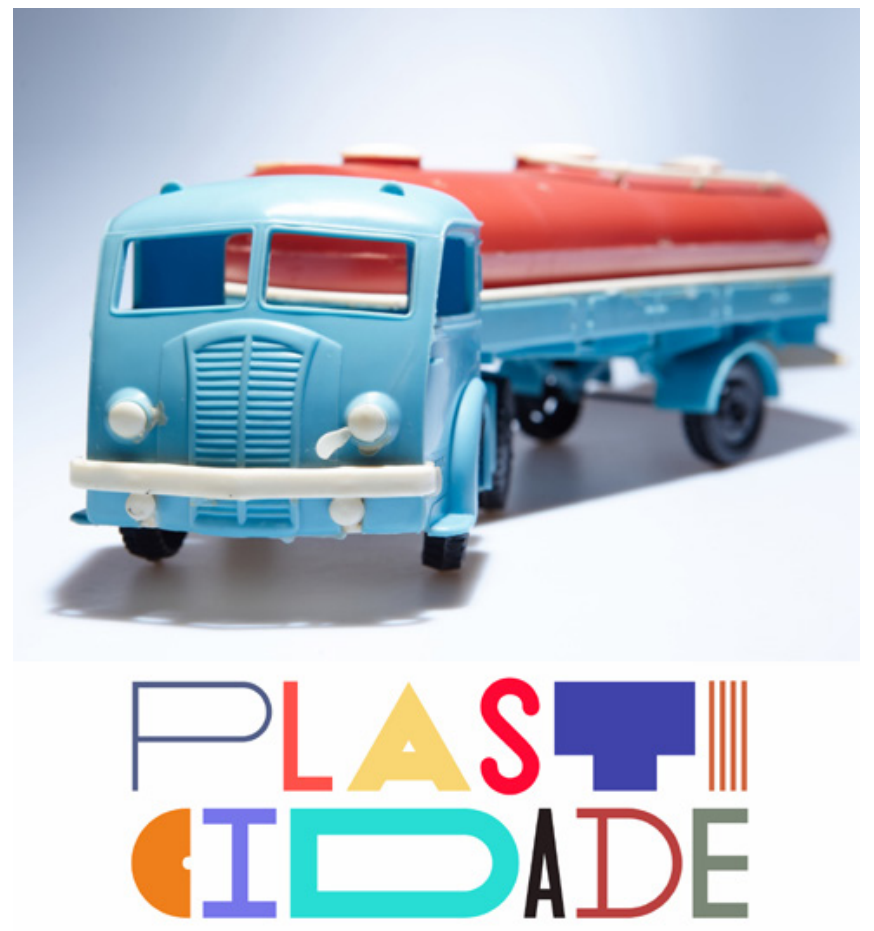

Uma História dos Plásticos em Portugal

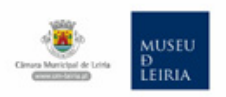

Figure 1. Exhibition poster of the exhibition "Plasticity - A History of Plastics in Portugal".

and other processing aids can be added, influencing the chemical and physical properties of the object. Also, from the point of view of conservation, it is already acknowledged that conserving plastics poses demanding challenges [4-6], especially because depending on the object's composition, different degradation factors can promote its decay. A wide range of ageing behaviours and degradation forms can be found, and in general, the lifespan of a plastic object is short, especially when compared to those of "traditional" materials such as stone, glass or wood [4-6]. Plastics are easily degraded by light, heat, oxygen and water, and "once initiated, degradation of plastics cannot be prevented, reversed or stopped" [4]. As the behaviour of plastics against aging is still not very predictable, knowing the chemical composition of a plastic is extremely useful to define safe preservation, intervention and display strategies. Also, it is fundamental to contribute to the history of the Portuguese plastics industry with a material and a technical perspective, which helps to identify chronologies behind the introduction of these "new" materials (plastics) into commercial circuits and to better understand how plastics have been introduced into the Portuguese society.

Infrared spectroscopy has been the most widely used technique to identify plastic types [7-8]. As stated by Picollo et al., "In fact, FT-IR analysis in the mid-infrared (mid-IR) spectral region gives researchers considerable ability to 
distinguish and identify polymers, and meets requirements such as microdestructiveness (and, in certain circumstances, nondestructiveness), cost effectiveness, and the availability of a wide range of commercial instrumentation" [8]. Accordingly, several conservation studies using IR spectroscopy for the study of plastics in art and design can be found in the literature [8-12]. The IR characterization can be performed by collecting micro samples or by in situ analyses, depending on the selected instrument.

Although the IR spectra and respective assignment of polymers such as PE, PP, PS, PMMA and plasticized and unplasticized PVC are more frequently found in publications [13-14], thermosetting, thermoplastic elastomers (TPU) and elastomeric polymers such as formaldehyde resins, polyurethane-based films and rubbers, respectively, have been poorly focused. Thus, this research intends to contribute to the fill of this gap by producing an ATR-FTIR spectral database of plastics found on historical objects from the Portuguese Plastics Industry. As plastics can also be found in artworks (for example, by Portuguese artists such as José Escada, João Vieira, Lourdes Castro and Ângelo de Sousa) and design (such Daciano da Costa and Eduardo Afonso Dias), other plastics such as cellulose acetate and polyurethane foams have been included as well, expanding the usefulness of the present study. In sum, this research includes thermoplastics, thermosetting, few elastomeric polymers and one thermoplastic elastomer. It presents a mid-IR spectral database of plastics and the respective IR assignment. Infrared spectroscopy in attenuated total reflection mode (ATR-FTIR) was selected because it is used as a common method of characterisation, making possible the comparison of the collected data with a broader body of published information.

\section{Materials and Methods}

\section{Materials}

From ca. 300 historical plastic objects that were gathered in the Museu de Leiria, 150 were selected for display. The selection was based on the objects' chronology (from the 1930s to the present), type of polymer, variety of uses (everyday, kitchen, toys, etc.), producers (factory) and aesthetic aspects. The objects came from different types of owners such as private collectors, factories, museums and research technological units; and in total, ca. 40 companies (mostly based in Portugal) were represented in the exhibition (Table 1). However, ca. 20 objects had no company attributed as no brand or label was found on the object or in the accessed documentation.

\section{Methodology and Infrared Spectroscopy}

For the creation of the exhibition contents, specialized bibliography and other sources were collected and assessed, especially magazines and other publications written by professional associations of the Portuguese processing plastics industry, such as the Portuguese Association of the Plastics Industry (APIP). Also, oral history played a major role in the preparation of the exhibition, and interviews with protagonists of the Portuguese industry were carried

Table 1. National and international plastic manufacturing and processing companies represented in the exhibition through historical plastic objects.

\begin{tabular}{lll}
\hline National & & International \\
\hline Adreta Plásticos (Sintra) & Moldoplásticos / Joluce Novares (Estarreja) & Apple \\
AEP - Plessey (Lisbon) & Osul (Espinho) & Fletro Optical Systems \\
Baquelite Liz (Leiria) & PIEP (Guimarães) & Philips \\
Cabopol (Leiria) & PLASFIL - Plásticos da Figueira (Figueira da Foz) \\
CDRSP (Marinha Grande) & Plasgal (Leiria) & Polaroid \\
Cires (Estarreja) & Plásticos do Lena (Leiria) & Pzo Warszawa \\
D. Dinis (Leiria) & Plásticos Santo António (Leiria) & Sawyer's \\
Edmar (Leiria) & Plastidom (Leiria) & \\
Fábrica Plásticos da Azóia (Lisboa) & Plastimar-indústria de Plásticos Penichense (Peniche) & \\
Faplana (Leiria) & Repsol Polímeros (Sines) & \\
Fendas (Matosinhos) & Romão e Rosa (Leiria) & \\
Hércules (Espinho) & Sie-sociedade Internacionalde Embalagens (Leiria) & \\
Indústria de Plásticos Hércules (Espinho) & Simala (Leiria) & \\
Janz (Lisbon) & Simplastic (Leiria) & \\
João Ruano (Leiria) & SIPE - Sociedade Industrial de Produtos Eléctricos & \\
Louropel Fábrica de Botões (V. N. de Famalicão) & (Lisbon) & \\
Metalúrgica Longra (Longra) & Sobro (Leiria) & \\
Moldemartin - Fábrica De Moldes De & Upla- Fábrica Universal de Plásticos (Braga) \\
Martingança (Alcobaça) & Vimar (n.a.) & \\
& &
\end{tabular}


out for ca. two years (2016-2018), and then carefully assessed. The interviewees also provided original documentation regarding the factories and the final plastic products. The gathered and produced documentation (photographs, catalogues, commercial documentation) was scanned, inventoried, studied and incorporated into the exhibition process. In addition to this procedure, the research project and the Museu de Leiria developed a campaign to collect plastic objects for the future constitution of the first historical collection of Portuguese plastic objects and for the planning of the exhibition. The campaign took place between 2017 and 2018 and was open to the whole country. It resulted from a call to the community to bring their own plastic items/objects to the museum. In that call, no criteria were defined as the goal was to involve the community in this request with no restrictions. The campaign was spread in local media and social networks. At the end, it was noticed that most of the delivered objects have been carefully maintained by their owners due to the representation of family or childhood memories. Also, some objects were described as memory carriers of the owner's previous work in the local factories.

It is important to note that the collected objects came from a wide variety of owners (private collectors, common individuals, factories, museums and research technological units). In general, the materials composing the objects were not indicated by their holders and the objects showed different condition grades. For example, highly dirt dilapidated expanded polystyrene buoys from the 1960s were present, as well as kitchen sets dating back to the same time but still used by the owners. Thus, the large number of collected objects (more than 300), and the diversity of plastic types that were after identified led to a wide variety of condition grades and conservation and restoration needs. Synthetic materials are generally regarded as indestructible, but those who take care of cultural heritage (storing and displaying them in museums, for example) know that plastics can show signs of degradation a few decades after their production. Thus, these objects were the subject of characterisation studies by the research project conservation team in order to study their potential incorporation into both the exhibition and collection of the Museu de Leiria in a responsible way. From the campaign, ca. 150 historical plastic objects have been selected for display, and from this selection, ca. 100 were materially characterised. The whole set of objects was not analysed as several objects were part of the same set. Infrared spectroscopy in attenuated total reflection mode (ATR-FTIR) was selected as good resolution spectra could be acquired in short time period (ca. fifteen seconds per spectrum) and both in situ (handheld) and sampling (benchtop) analyses could be carried out without any sample preparation. However, the strong contact required by the technique, made ATR-FTIR not appropriate for the in situ analysis of flexible, brittle and/or complex-shaped plastic objects. For these cases, small samples (ca. $1 \mathrm{~mm}$ max.) were collected with a Ted Pella micro tool and a scalpel under magnification (10x) and fibre optic light sources. The whole set of samples was stored between two concave glass slides, used as sample holders. For each polymer, the mid-IR spectrum and the main IR bands have been identified. The bands allowing the identification of the polymer are highlighted as IR markers. Since most of the objects came to the Museu de Leiria without being prepared for display, cleaning protocols according to plastic type have been tested and followed. The cleaning protocols were established taking into consideration the previous research work developed by the European POPART project [5] and some preliminary cleaning tests carried out by the conservators from the Conservation and Restoration Department (DCR) from the Faculdade de Ciências e Tecnologia - Universidade NOVA de Lisboa. For the cleaning tests, the research project gathered a set of objects (acquired online and on local fairs) showing similar dirt and condition grades, with the purpose of serving the conservation and restoration investigation. This allowed to previously assess the safety and efficiency of some cleaning procedures before intervening the historical objects selected for display.

Infrared spectroscopy in attenuated total reflection (ATR-FTIR) was carried out with the Handheld Agilent 4300 spectrophotometer, equipped with a ZnSe beam splitter, a Michelson interferometer and a thermoelectrically cooled DTGS detector. Spectra were acquired with a diamond ATR interface, 32 scans and 4 and/or $8 \mathrm{~cm}^{-1}$ resolution. This ATR interface allows the analysis of samples with a minimum size of 200 microns. Spectral analysis was performed using OriginPro 8 software. The spectra are shown as acquired, without baseline corrections or normalizations.

\section{Results}

\section{The history of the Portuguese plastics industry}

According to Callapez, the introduction of plastic industries in Portugal took place in the 1930s [2]. For this entrance, two national conditions played a major role: the wish of the Portuguese government to renovate its industrial sector and the urgency of the country to get closer to what was happening abroad [2]. However, additional economical and historical factors have also contributed to this desire: $i$ ) the Wall Street Crash of 1929; ii) the national implementation of Regime do Condicionamento Industrial (an effective system for industrial protectionism) in 1931; iii) the opening of the Grande Exposição da Indústria Portuguesa (Great Exhibition of Portuguese Industry) in 1932 (Lisbon); and iv) the opening of the I Congresso da Indústria Portuguesa (1st Congress of Portuguese Industry) in 1933 (Lisbon) [15]. In detail, whereas the depression of 1929 (i) resulted in the recognition that national industries needed to be protected (ii), the economic recovery that followed resulted in two positive outcomes in Portugal: the Great Exhibition of Portuguese Industry (iii), 
and the 1st Congress of Portuguese Industry (iv) [2]. The last two events gathered important figures from the industrial sector [15]. From this context, the first two Portuguese plastic companies were founded, Sociedade Industrial de Produtos Eléctricos (SIPE) in Lisbon, and Nobre \& Silva in Leiria. The need for fuel, namely gasoline for transports, after World War II, has boosted the increase in oil consumption and, therefore, the use of its by-products. Plastics and synthetic rubbers have become commercially important throughout the twentieth century, concomitantly with an exponential growth of the plastics industry. Between 1940s-1960, Portugal joined the Marshall Plan (1948) and entered into the European Free Trade Association (1959) [3, 16-18]. Thus, the Portuguese plastics industry found a favourable economic environment for its development and several plastic companies were developed during this period [3]. Plastic associations and promotional efforts were implemented by the Portuguese Government. Grémio Nacional dos Industriais de Composição e Transformaçãa de Matérias Plásticas, GNICTMP (National Corporation of Plastics Materials Converters) was founded in 1957 [2] and Instituto Nacional de Investigação Industrial (INII) (National Institute of Industrial Research) in 1959 [17]. From these important associations, national publications reporting the plastics production and consumption in Portugal were launched. In 1956, there were already in Portugal 45 manufacturing units related to the plastics industry, producing predominantly for the electric, toy, household goods and civil construction sectors [2, 19-20]. It should be considered that the plastics processing industry was born in Portugal in the shadow of the mould industry, so both the history of the mould and plastics industries in Portugal are inextricably linked [2, 19-20]. Since the eighteenth century, the glass industry in Marinha Grande (central Portugal) used the blow moulding technique in the manufacturing process - the vitreous mass was placed in a mould and blown, giving to the piece the shape of the mould interior $[2,19-20]$. The moulding technique was also used for plastics processing by compression or injection, for example. Thus, through a technological transference process, the region of Leiria (Leiria - Marinha Grande axis) appears as a suitable place for the installation of plastic processing industries [2, 19-20]. In 1936, the company Nobre $\&$ Silva (Leiria) played a relevant role by ordering a mould for the manufacture of bakelite caps for a perfume bottle to the mould company, Aires Roque \& Irmão (that until then, was only producing moulds for the glass industry) [2, 19-20].

In sum, this historical record shows that the region of Leiria is closely related to the origin of the plastics processing industry in Portugal, fully justifying the institutional partnership between the research project, "The Triumph of Bakelite" and the Municipality of Leiria | Museu de Leiria in the organization of an exhibition about the history of plastics. Also, from a survey of the geographical origin of the processing plastic industries represented in the displayed objects, Leiria is the region where most of these companies were founded (Figure 2). This is in line with the literature, which mentions Leiria as the largest plastics processing centre in Portugal in the 1940s and 1950s [21-23].

\section{The exhibition "Plasticity-A History of Plastics in Portugal"}

The discourse of the exhibition "Plasticity - A History of Plastics in Portugal" was divided into one introductory section and five main sections dedicated to: 1 - the material; 2 - the industry; 3 - the history through objects; 4 - the new plastics; and 5 - the plastics in art and design. In addition, a different room in the museum was also selected to show additional aspects within the "Plasticity" exhibition, changing every three months. This space was introduced to create a more dynamic programme, capable of exploring other branches of plastics (for instance, plastics in art, plastic toys produced in Leiria, or a specific home division such as the kitchen). Regarding the third and fifth sections, due to the presence of historical and artistic objects coming from different institutional holders and private owners, these

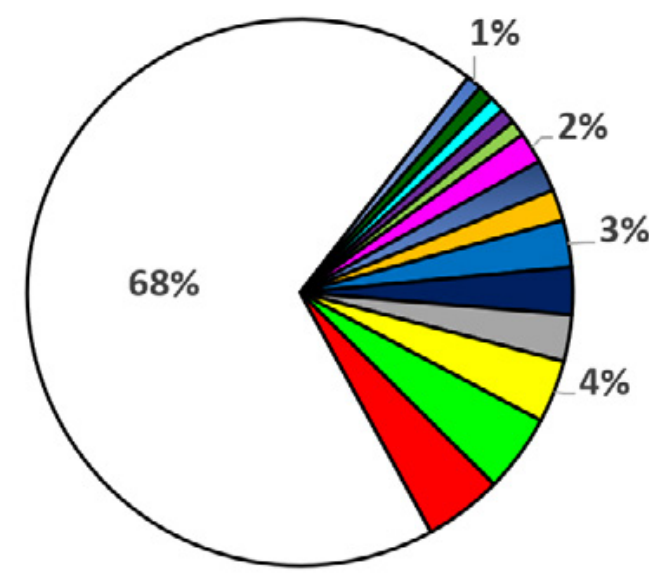

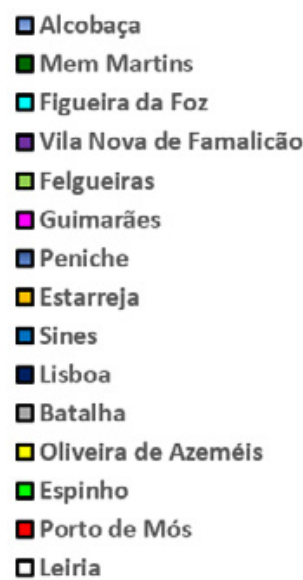

Figure 2. Frequency of objects (\%) per processing plastic industry location in Portugal, as represented in the exhibition 'Plasticity-A History of Plastics in Portugal': ca. 1 \% (Alcobaça, Mem Martins, Figueira da Foz, Vila Nova de Famalicão and Felgueiras), ca. 2 \% (Guimarães, Peniche and Estarreja), ca. 3 \% (Sines, Lisboa and Batalha), ca. 4 \% (Oliveira de Azeméis, Espinho and Porto de Mós), and ca. 68 \% (Leiria). 
spaces were the ones to which the knowledge of conservation science and practice was mostly needed.

In the third section, the exhibition contents were treated chronologically, from 1930 to the present, and each age of the Portuguese plastic industry was communicated through the display of selected plastic objects. Both commodity (as found on daily life objects) and more technical (as found in medicine and aerospace engineering items) plastics have been included, showing the wide diversity of sectors to which plastics have been contributing to. Also, in this space, the visitor was confronted with the use of plastic instead of more traditional materials such as glass, ceramics and metal, through a dialogue of objects loaned by other museums of the Leiria Municipality and made by different materials, side by side to each other. Consequently, this exhibition path allowed the visitor to gain awareness of how his/her cultural identity largely lies in inanimate objects, full of meaning, even though produced with a material that has been disregarded by some people due to its apparent lack of value (cheap and ordinary). In both third and fifth sections, plastics were shown as artistic material supports to which several Portuguese artists (such as José Escada and Nuno Sousa Vieira) and designers (Daciano da Costa and Eduardo Afonso Dias) have been largely attracted to. Also, in the atrium of the Museu de Leiria, one installation artwork was made by the "Coletivo Til", a collective of plastic artists.

\section{The contribution of infrared spectroscopy to the History of the Portuguese Plastics Industry \\ Objects as material testimonies of the Portuguese plastics Industry}

From ATR-FTIR, ca. 15 different types of polymers were identified in the historical objects selected for display (examples are shown in Figure 3 and Figure 4). The objects material composition was classified according to the chemical nature of the polymer. From this material survey, the diversity of plastics processed by the national industry was demonstrated, as well as the fondness of more avantgarde Portuguese artists and designers by these "new" materials. Polyethylene (PE), polypropylene (PP), polystyrene (PS), poly(methyl methacrylate) (PMMA), plasticized and unplasticized poly(vinyl chloride) (PVC), polycarbonate (PC), polyoxymethylene (POM), poly(styrene-acrylonitrile) (SAN) and poly(acrylonitrile-butadiene-styrene) (ABS) are examples of the synthetic thermoplastic polymers identified (Figure 5); whereas melamine-formaldehyde (MF), phenol-formaldehyde (PF) and urea-formaldehyde (UF) are examples of synthetic thermosetting resins (Figure 6).
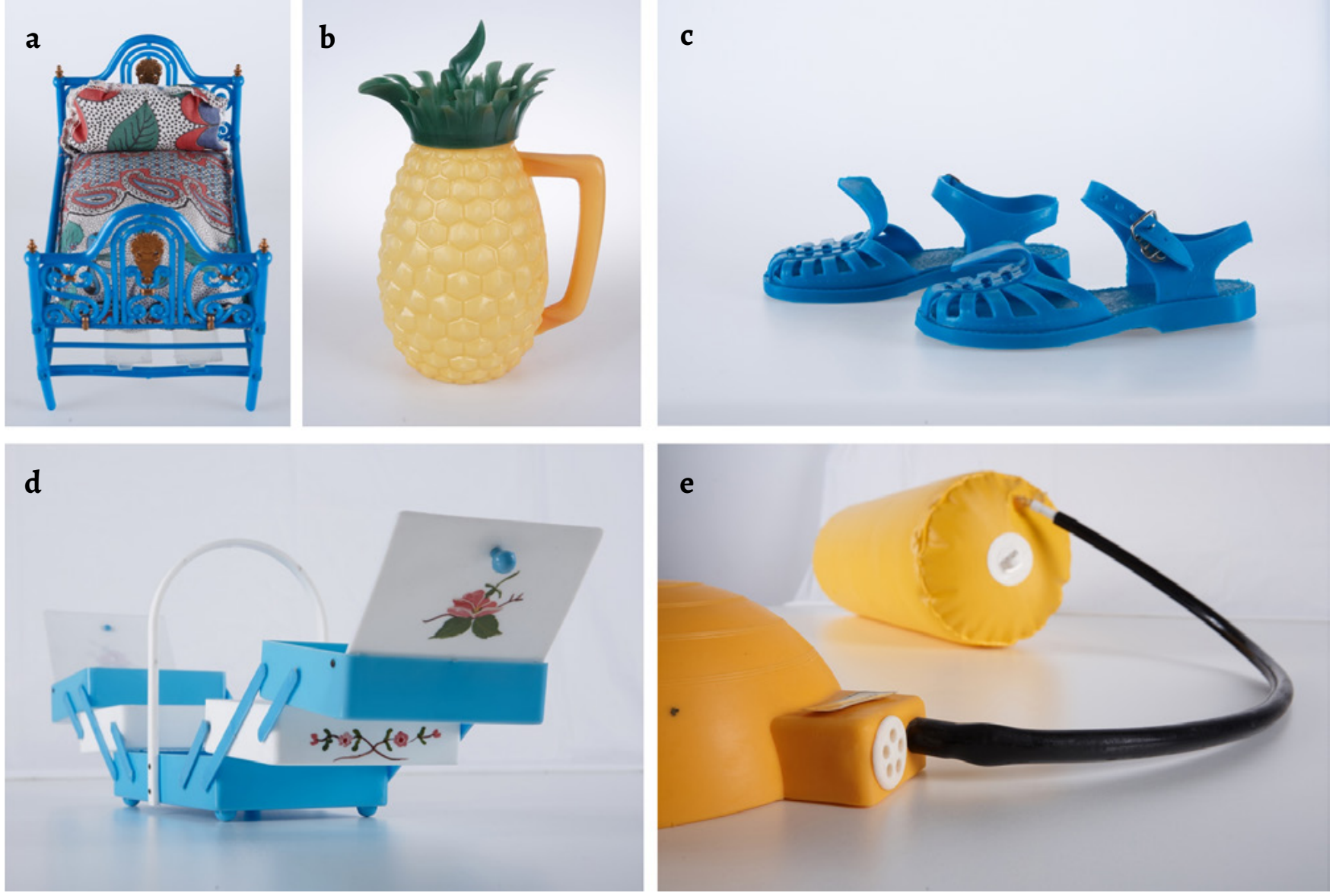

Figure 3. Examples of historical objects from the Portuguese plastics industry: $a$ ) miniature bed in polypropylene (PP), produced by Lena (Leiria); $b$ ) pineapple-shaped pitcher in polyethylene (PE), unknown manufacturer; c) children sandals in poly(vinyl chloride) (plasticized PVC), produced by Edmar (Leiria); d) sewing box in polystyrene (PS), produced by Baquelite Liz (Leiria); and e) Colchão Mágico float and filling pump in poly(vinyl chloride) (plasticized PVC), produced by Adreta Plásticos (Sintra) and Ruano (Leiria), respectively. Photos: Câmara Municipal de Leiria. 

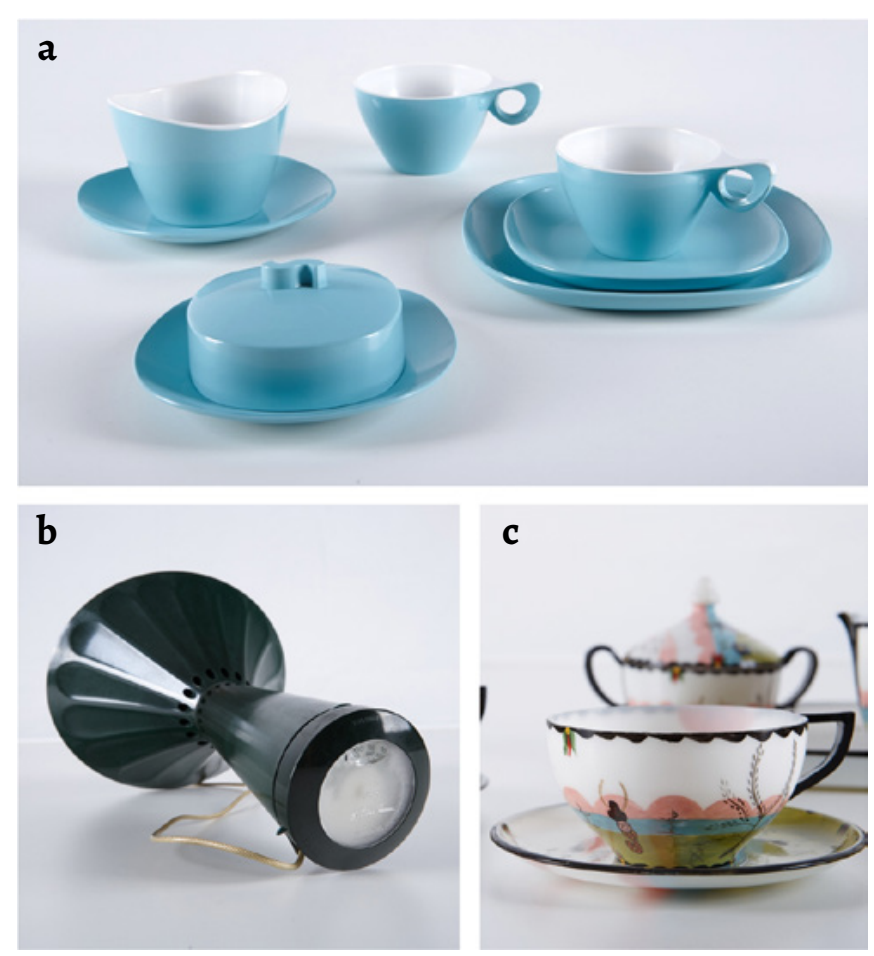

Figure 4. Examples of historical objects from the Portuguese plastics industry made of formaldehyde resins: a) tableware in melamine-formaldehyde (MF) produced by Edmar (Leiria); b) radio La la la in phenol-formaldehyde (PF) produced by Faplana (Leiria); and c) tea set in urea-formaldehyde (UF) produced by Baquelite Liz (Leiria). Photos: Câmara Municipal de Leiria.
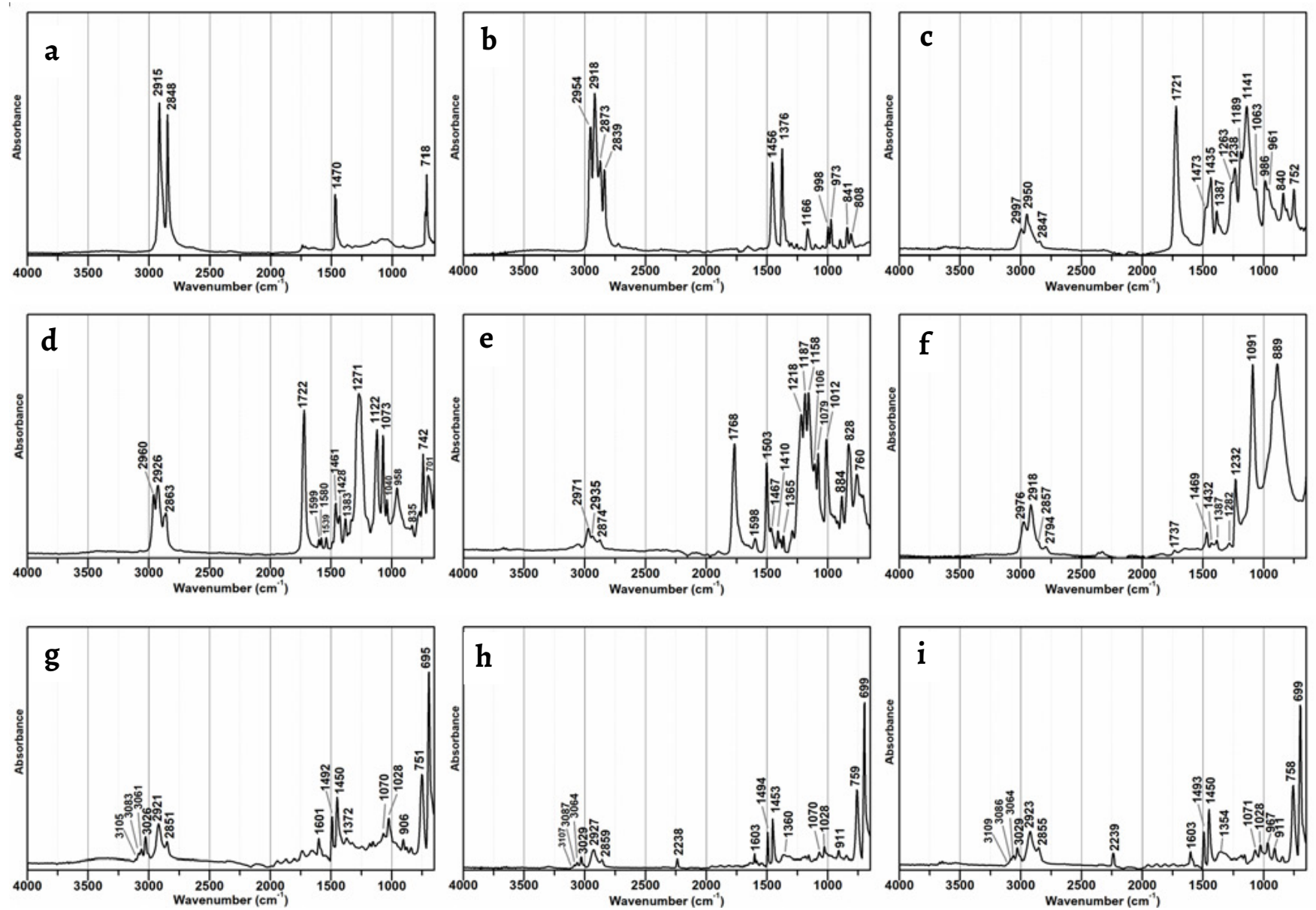

Figure 5. Infrared spectra (ATR-FTIR) of historical objects from the Portuguese plastic industry: a) polyethylene pot produced by SIE - Sociedade Internacional de Embalagens (Leiria); b) polypropylene miniature bed produced by Fábrica de Plásticos do Lena (Leiria); c) poly(methyl methacrylate) bus vehicle light produced by Plasgal (Leiria); d) plasticized poly(vinyl chloride) Colchão Mágico produced by Adreta Plásticos (Sintra); e) polycarbonate tap from the thermo barrel Thermo Olympic produced by Simplastic (Marinha Grande); f) polyoxymethylene net from a water counter produced by Janz (Leiria); $g$ ) polystyrene bread box produced by Plastidom - Plásticos Industriais e Domésticos SA (Leiria); $h$ ) poly(styrene-acrylonitrile) cups from the thermo barrel Thermo Olympic produced by Simplastic (Leiria, Portugal); i) poly(acrylonitrile-butadiene-styrene) citrus press produced by Edmar (Leiria). 

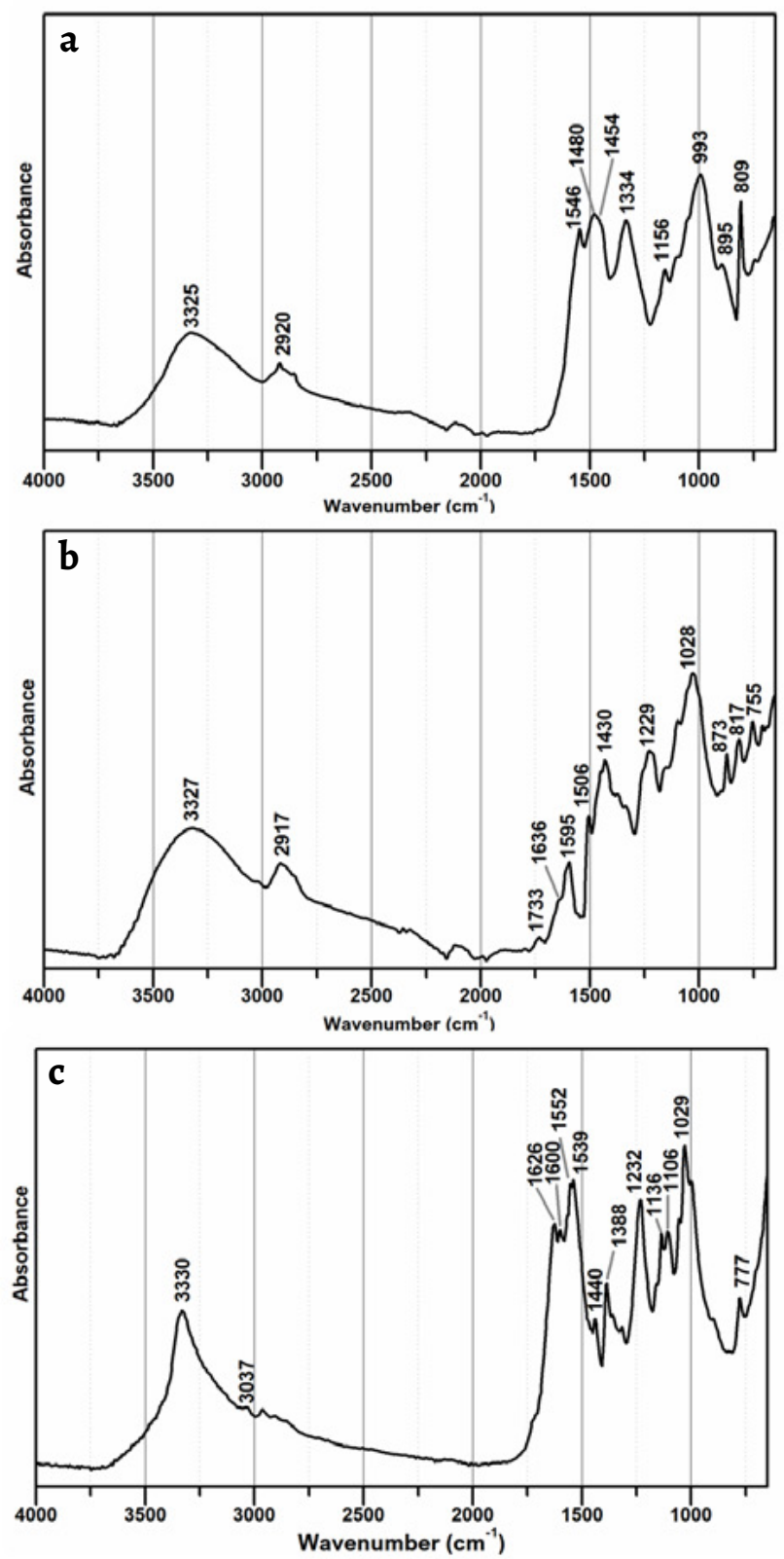

Figure 6. Infrared spectra (ATR-FTIR) of historical objects from the Portuguese plastic industry made of formaldehyde resins: a) melamineformaldehyde tableware set produced by Edmar (Leiria); b) phenolformaldehyde La La La radio by Philippe Starck produced by Faplana (Leiria); c) urea-formaldehyde tea set produced by Baquelite Liz (Leiria).

Concerning some of the design and art objects in display, cellulose acetate, ether-based polyurethane, ester-based polyurethane and styrene-butadiene based-rubber (SBR) (Figure 7) were also found. Table 2 summarizes the main ATR-FTIR absorption bands of the identified polymers. For the assignment of the bands, previous studies [13-14, 24-54] were accessed along with information obtained by the manufacturers. Also, in some cases, additives such as plasticizers and impact modifiers have been detected in the IR spectrum. In the analysis of flexible PVC objects (e.g. sandals and inflatables), the presence of phthalates was commonly identified (Table 2) by the detection of characteristic bands at $1722 \mathrm{~cm}^{-1}$ ( $\mathrm{C}=\mathrm{O}$ stretching), 1599 and $1580 \mathrm{~cm}^{-1}$ (C-C stretching, aromatic ring), and 1271, 1122 and $1073 \mathrm{~cm}^{-1}$ (C-O stretching). In the case of impact modifiers, some spectra of rigid objects made of polystyrene showed a weak absorption band at ca. $967 \mathrm{~cm}^{-1}$, which may correspond to the bending vibration of $\mathrm{C}-\mathrm{H}$ in polybutadiene [36]. As mentioned by Murphy, the addition of impact modifiers in rigid plastics has been carried out by the industry when plastics show high and undesired inherent brittleness [54]. Usually, the mechanism involves the introduction of a component capable of absorbing or dissipating the energy of an impact, and butadiene-based rubber has been one of the most selected additives for this purpose [54]. Thus, although the spectra of historical PS objects such as the truck (Figure 1) and the sewing box (Figure 3) did not show the band at ca. $967 \mathrm{~cm}^{-1}$, examples of objects such as the red calculator produced by Osul (Espinho) showed this band (Figure 8), possibly indicating the presence of impact modifiers based on butadiene-based rubber to enhance its resistance to the impact of children' fingers in the plastic keys.

In addition, from the overall material characterisation of the historical objects, a statistical analysis of the collected data was carried out, making possible the launching of preliminary interpretations concerning the Portuguese plastics industry. As examples, Figure 9 indicates a high presence of polyethylene and polystyrene in the historical objects, being followed by polypropylene and poly(vinyl chloride). Regarding these polymers, Figure 10 (yellow bar) also shows that this preference was mostly evident during the 1960s, especially for polymers such as PS, PE and PVC. This not only is in accordance with information collected from oral interviews with former and current workers of the Portuguese Plastics Industry, as follows information accessed on national periodicals and magazines. For instance, the Portuguese Plastics magazine [21-22] mentions that the processing of thermoplastics increased by $300 \%$ between 1966 and 1972, being PE, PP, PVC and PS the main polymers in use. According to [22], the dominance of these four polymers in the thermoplastics market was not only observed in Portugal, but also worldwide. A possible reason contributing to this growth could have been the European economic opening during the 1960s, which forced Portugal to expand its economy to abroad, and with that, to develop and advance the plastics industry in the country [23]. In addition to these findings, it was also curious to observe in Figure 10 that thermosetting resins such as PF and MF crossed several decades of the Portuguese plastics processing, even though they have been commonly associated to the birth of the Portuguese Plastics Industry. As shown, these resins were used in objects dated from the 1930s to the 1990s (Figure 10), proving that PF and MF continued to be used by the Portuguese industry in modern and design objects. 

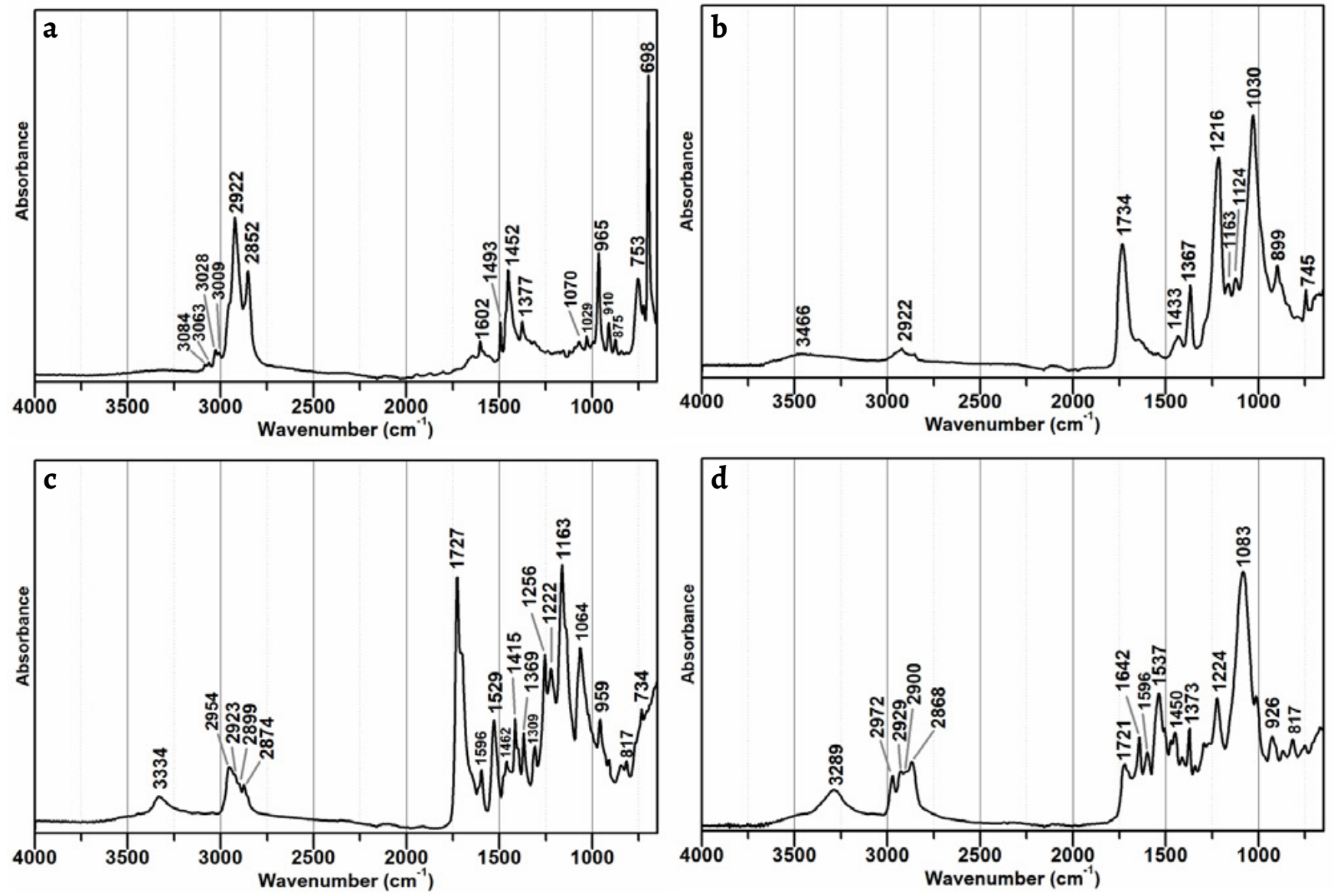

Figure 7. Infrared spectra (ATR-FTIR) of historical objects from the Portuguese plastic industry and one plastic reference: $a$ ) styrene-butadiene rubber sheet produced by Simala (Leiria); $b$ ) cellulose acetate sheet produced by Mazuchelli (Italy); $c$ ) ester-based polyurethane coating from a children raincoat produced by F. Roda 1 Pintarola; and d) ether-based polyurethane foam from Cortez chair designed by Daciano da Costa for Metalúrgica da Longra (Longra).

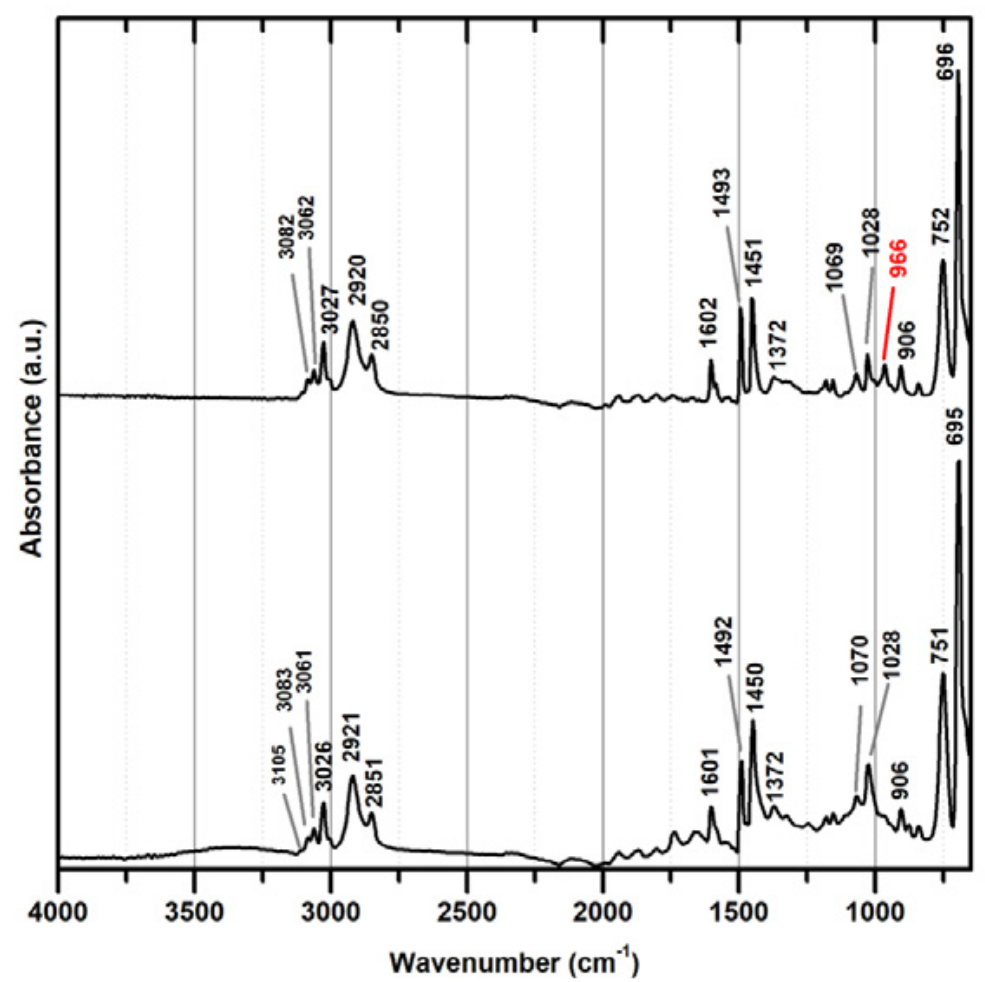

a

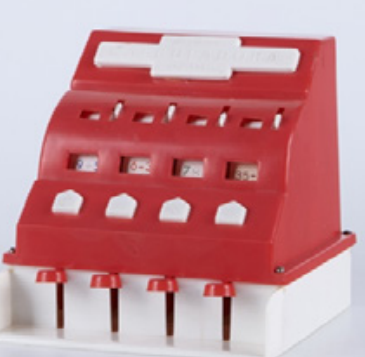

b

b

Figure 8. Infrared spectra (ATR-FTIR) of the calculator produced by Osul (a) and the sewing box produced by Baquelite Liz (b), both in polystyrene (PS). The frequency of the band highlighted in red was attributed to the presence of impact modifiers based on polybutadiene-based rubber. Photos: Câmara Municipal de Leiria. 
S. França de Sá, S. M. da Cruz, M. E. Callapez, V. Carvalho

Table 2. Assignment of the main absorbance bands in the infrared spectrum (ATR-FTIR) for the polymers identified in the Portuguese historical plastic objects. The IR markers are shown in bold.

\begin{tabular}{|c|c|c|}
\hline Polyethylene (PE) & Polypropylene (PP) & \multirow{2}{*}{ Assignment $[25-27,31,36]$} \\
\hline \multicolumn{2}{|c|}{ Band $\left(\mathrm{cm}^{-1}\right)$} & \\
\hline & $2954(s)$ & $v_{\mathrm{as}}\left(\mathrm{C}-\mathrm{H}_{3}\right)$ \\
\hline \multirow[t]{2}{*}{$2915(\mathrm{~s})$} & $2918(s)$ & $v_{a s}\left(C-H_{2}\right)$ \\
\hline & $2873(\mathrm{~m})$ & $v_{\mathrm{S}}\left(\mathrm{C}-\mathrm{H}_{3}\right)$ \\
\hline $2848(s)$ & $2839(\mathrm{~m})$ & $v_{S}\left(C-H_{2}\right)$ \\
\hline \multirow[t]{7}{*}{$1470(\mathrm{~m})$} & $1456(\mathrm{~m})$ & $\delta_{\mathrm{as}}\left(\mathrm{C}-\mathrm{H}_{2}\right)$ \\
\hline & $1376(\mathrm{~m})$ & $\delta_{\mathrm{S}}\left(\mathrm{C}-\mathrm{H}_{3}\right)$ \\
\hline & $1166(w)$ & $\delta\left(\mathrm{C}-\mathrm{H}_{3}\right), v(\mathrm{C}-\mathrm{C})$ \\
\hline & $998(w)$ & $\delta\left(\mathrm{C}-\mathrm{H}_{2}\right), \delta(\mathrm{C}-\mathrm{H})$ \\
\hline & $973(w)$ & $\delta\left(\mathrm{C}-\mathrm{H}_{3}\right), v_{\mathrm{S}}(\mathrm{C}-\mathrm{C})$ \\
\hline & $841(w)$ & $\delta\left(\mathrm{C}-\mathrm{H}_{2}\right), v\left(\mathrm{C}-\mathrm{C}-\mathrm{H}_{3}\right), \delta\left(\mathrm{C}-\mathrm{H}_{3}\right)$ \\
\hline & $808(w)$ & $\delta\left(\mathrm{C}-\mathrm{H}_{2}\right), v_{\mathrm{S}}(\mathrm{C}-\mathrm{C})$ \\
\hline $718(\mathrm{~m})$ & & $\delta\left(\mathrm{C}-\mathrm{H}\left(-\mathrm{C}-\mathrm{H}_{2}\right)\right)$ \\
\hline
\end{tabular}

Polycarbonate (PC)

Plasticized poly(vinyl chloride) (plasticized PVC)

\begin{tabular}{|c|c|c|c|}
\hline Band $\left(\mathrm{cm}^{-1}\right)$ & Assignment $[28-31,36]$ & Band $\left(\mathrm{cm}^{-1}\right)$ & Assignment [31-36] \\
\hline $3150-3025(w)$ & $v(\mathrm{C}-\mathrm{H})$ aromatic ring & $2960(\mathrm{~m})$ & $v_{a s}(C-H)$ \\
\hline $2971(w)$ & $v_{\text {as }}\left(\mathrm{C}-\mathrm{H}_{3}\right)$ & $2926(\mathrm{~m})$ & $\operatorname{vas}\left(C-H_{2}\right)$ \\
\hline $2935(w)$ & $v_{\text {as }}\left(C-\mathrm{H}_{3}\right)$ & $2863(\mathrm{~m})$ & $v_{S}\left(C-H_{2}\right)$ \\
\hline $2874(w)$ & $v_{S}\left(C-H_{3}\right)$ & $1722(s)$ & $v(\mathrm{C}=\mathrm{O})$ plasticizer \\
\hline $1768(\mathrm{~m})$ & $v(\mathrm{C}=\mathrm{O})$ carbonate & $1599(w)$ & $v(C-C)$ plasticizer \\
\hline $1598(w)$ & $v(C-C)$ aromatic ring & $1580(w)$ & $v(C-C)$ plasticizer \\
\hline $1503(\mathrm{~m})$ & $v(C-C)$ aromatic ring & $1539(w)$ & $\delta_{\mathrm{as}}\left(\mathrm{C}-\mathrm{H}\left(-\mathrm{C}-\mathrm{H}_{2}\right)\right)$ \\
\hline $1467(w)$ & $\delta_{\text {as }}\left(\mathrm{C}-\mathrm{H}\left(-\mathrm{C}-\mathrm{H}_{2}\right)\right)$ & $1461(\mathrm{~m})$ & $\delta\left(\mathrm{CH}_{2}\right), \delta_{\mathrm{S}}\left(\mathrm{CH}_{3}\right)$ plasticizer \\
\hline $1410(w)$ & $\delta_{\mathrm{as}}\left(\mathrm{C}-\mathrm{H}\left(-\mathrm{C}-\mathrm{H}_{3}\right)\right), v(\mathrm{C}-\mathrm{C})$ aromatic ring & $1428(\mathrm{~m})$ & $\delta\left(\mathrm{C}-\mathrm{H}_{2}\right)$ \\
\hline $1365(w)$ & $\delta_{\mathrm{S}}\left(\mathrm{C}-\mathrm{H}_{3}\right)$ & $1383(\mathrm{~m})$ & $\delta_{\mathrm{as}}\left(\mathrm{CH}_{3}\right)$ plasticizer \\
\hline $1218(s), 1187(s), 1158(s)$ & $v(\mathrm{C}-\mathrm{O})$ carbonate & $1271(\mathrm{~s}), 1122(\mathrm{~s}), 1073(\mathrm{~s})$ & $v(\mathrm{C}-\mathrm{O})$ plasticizer \\
\hline $1106(\mathrm{~m})$ & $\delta(\mathrm{C}-\mathrm{H})$ aromatic ring & $1040(\mathrm{~m})$ & plasticizer \\
\hline $1079(\mathrm{~m})$ & $\delta\left(\mathrm{C}-\mathrm{H}_{3}\right), v(\mathrm{C}-\mathrm{C})$ & $958(\mathrm{~m})$ & $\delta\left(\mathrm{C}-\mathrm{H}_{2}\right)$ \\
\hline $1012(\mathrm{~m}), \mathbf{8 8 4}(\mathrm{m})$ & $\delta(\mathrm{C}-\mathrm{H})$ aromatic ring & $835(w)$ & $v(\mathrm{C}-\mathrm{Cl})$ \\
\hline $828(\mathrm{~m})$ & $\delta(\mathrm{C}-\mathrm{H})$ aromatic ring, $v\left(\mathrm{C}\left(\mathrm{C}-\mathrm{H}_{3}\right)_{2}\right)$ & $742(\mathrm{~m})$ & $v(\mathrm{C}-\mathrm{O}), \delta(\mathrm{C}-\mathrm{H})$ plasticizer \\
\hline $760(\mathrm{~m})$ & $\delta(\mathrm{C}-\mathrm{H})$ aromatic ring & $701(\mathrm{~m})$ & $v(\mathrm{C}-\mathrm{Cl})$ \\
\hline
\end{tabular}

Poly(methyl methacrylate) (PMMA)

Polyoxymethylene (POM, also known as polyacetal)

\begin{tabular}{cccc} 
Band $\left(\mathbf{c m}^{-1}\right)$ & Assignment $[31-36]$ & Band $\left(\mathbf{c m}^{-1}\right)$ & Assignment $[45-46]$ \\
\hline $2997(\mathrm{w})$ & $v_{\mathrm{as}}\left(\mathrm{C}-\mathrm{H}_{3}\right)$ & $\mathbf{2 9 7 6}(\mathrm{m})$ & $v\left(\mathrm{C}-\mathrm{H}_{2}\right)$ \\
$2950(\mathrm{w})$ & $v_{\mathrm{as}}\left(\mathrm{C}-\mathrm{H}_{2}\right)$ & $\mathbf{2 9 1 8}(\mathrm{m})$ & $v\left(\mathrm{C}-\mathrm{H}_{2}\right)$ \\
$2847(\mathrm{w})$ & $v_{\mathrm{S}}\left(\mathrm{C}-\mathrm{H}_{2}\right)$ & $2857(\mathrm{sld})$ & \\
$\mathbf{1 7 2 1}(\mathrm{s})$ & $v(\mathrm{C}=\mathrm{O})$ & $2794(\mathrm{w})$ & $v(\mathrm{C}=\mathrm{O})$ \\
$1473(\mathrm{sld})$ & $\delta_{\mathrm{as}}\left(\mathrm{CH}_{3}\right)$ & $1737(\mathrm{w})$ & $\delta\left(\mathrm{C}-\mathrm{H}_{2}\right)$ \\
$\mathbf{1 4 3 5}(\mathrm{m})$ & $\delta_{\mathrm{S}}\left(\mathrm{C}-\mathrm{H}_{2}\right), \delta\left(\mathrm{O}-\mathrm{CH}_{3}\right)$ & $1469(\mathrm{w})$ & $\delta\left(\mathrm{C}-\mathrm{H}_{2}\right)$ \\
$1387(\mathrm{w})$ & $\delta_{\mathrm{S}}\left(\mathrm{C}-\mathrm{H}_{3}\right)$ & $1432(\mathrm{w})$ & $\delta\left(\mathrm{C}-\mathrm{H}_{2}\right)$ \\
$1263(\mathrm{sld}), \mathbf{1 2 3 8}(\mathrm{m})$ & $v(\mathrm{C}-\mathrm{O})$ & $1387(\mathrm{w})$ & $\delta\left(\mathrm{C}-\mathrm{H}_{2}\right)$ \\
$\mathbf{1 1 8 9}(\mathrm{m})$ & $v(\mathrm{C}-\mathrm{O}), \delta\left(\mathrm{C}-\mathrm{H}_{3}\right)$ & $1282(\mathrm{w})$ & $\delta\left(\mathrm{C}-\mathrm{H}_{2}\right)$ and $v(\mathrm{C}-\mathrm{O})$ \\
$\mathbf{1 1 4 1}(\mathrm{s})$ & $v(\mathrm{C}-\mathrm{O})$ & $\mathbf{1 2 3 2}(\mathrm{m})$ & $\delta\left(\mathrm{C}-\mathrm{H}_{2}\right)$ and $v(\mathrm{C}-\mathrm{O})$ \\
$\mathbf{9 8 6}(\mathrm{m})$ & $v(\mathrm{C}-\mathrm{O}-\mathrm{C}), \delta\left(\mathrm{C}-\mathrm{H}_{3}\right)$ & $\mathbf{1 0 9 1}(\mathrm{s})$ & $\delta\left(\mathrm{C}-\mathrm{H}_{2}\right)$ and $v(\mathrm{C}-\mathrm{O})$ \\
$\mathbf{8 4 0}(\mathrm{m})$ & Skeletal & $\mathbf{8 8 9}(\mathrm{s})$ & \\
$752(\mathrm{~m})$ & Skeletal $+\delta\left(\mathrm{CH}_{2}\right)$ & &
\end{tabular}


Plastics that made history

Table 2. (Continued)

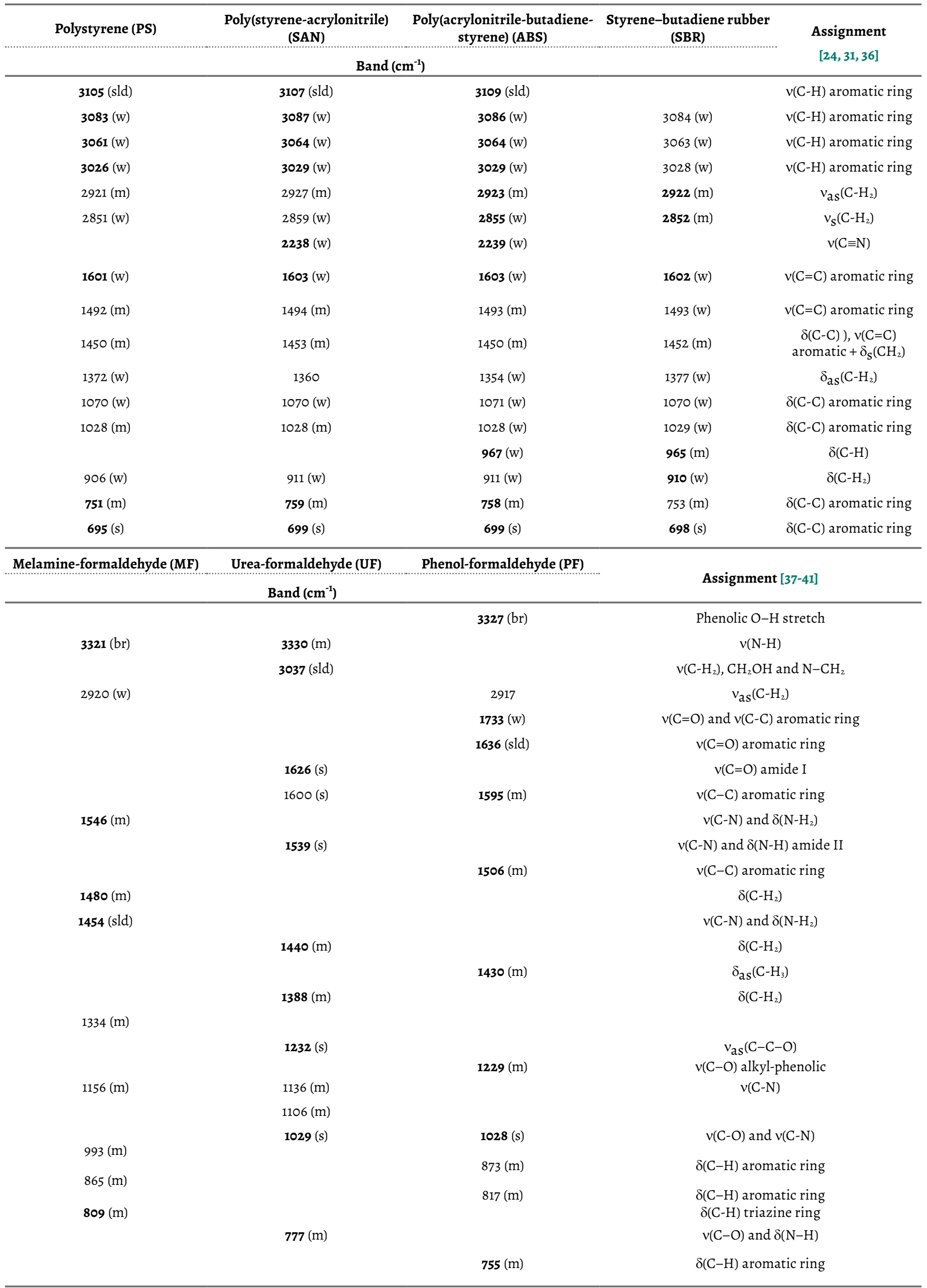


S. França de Sá, S. M. da Cruz, M. E. Callapez, V. Carvalho

Table 2. (Continued)

\begin{tabular}{|c|c|c|c|}
\hline $\begin{array}{l}\text { Ether-based polyurethane } \\
\text { foam (ether-based PUR) }\end{array}$ & $\begin{array}{l}\text { Ester-based polyurethane } \\
\text { coating (ester-based TPU) }\end{array}$ & Cellulose acetate (CA) & \multirow[t]{2}{*}{ Assignment [47-53] } \\
\hline \multicolumn{3}{|c|}{ Band $\left(\mathrm{cm}^{-1}\right)$} & \\
\hline & & 3466 (br) & $v(\mathrm{O}-\mathrm{H})$ \\
\hline $3289(\mathrm{~m})$ & $3334(w)$ & & $v(\mathrm{~N}-\mathrm{H})$ \\
\hline $2972(\mathrm{~m})$ & $2954(\mathrm{~m})$ & & $v_{\mathrm{as}}\left(\mathrm{C}-\mathrm{H}_{2}\right)$ \\
\hline $2929(\mathrm{~m})$ & 2923 (sld) & $2922(w)$ & $v_{\mathrm{as}}\left(\mathrm{C}-\mathrm{H}_{2}\right)$ \\
\hline \multirow[t]{2}{*}{2900 (sld) } & 2899 (sld) & & $v_{\mathrm{S}}\left(\mathrm{C}-\mathrm{H}_{2}\right)$ \\
\hline & $2874(w)$ & & $v_{\mathrm{S}}\left(\mathrm{C}-\mathrm{H}_{2}\right)$ \\
\hline \multirow[t]{3}{*}{$2868(\mathrm{~m})$} & & & $\delta\left(\mathrm{C}-\mathrm{H}_{3}\right)$ and $v_{\mathrm{S}}\left(\mathrm{C}-\mathrm{H}_{2}\right)$ \\
\hline & & $1734(\mathrm{~m})$ & $v_{\mathrm{S}}(\mathrm{C}=\mathrm{O})$ ester \\
\hline & $1727(s)$ & & $v(\mathrm{C}=\mathrm{O})$ ester and urethane \\
\hline $1721(\mathrm{~m})$ & & & $v(\mathrm{C}=\mathrm{O})$ urethane \\
\hline $1642(\mathrm{~m})$ & & & $v(C=O)$ urea \\
\hline $1599(\mathrm{~m})$ & $1596(w)$ & & $v(\mathrm{C}=\mathrm{C})$ aromatic ring \\
\hline $1537(\mathrm{~m})$ & $1529(\mathrm{~m})$ & & $v(\mathrm{C}-\mathrm{N})$ and $\delta(\mathrm{N}-\mathrm{H})$ \\
\hline \multirow[t]{3}{*}{$1450(\mathrm{~m})$} & $1462(w)$ & & $\delta\left(\mathrm{C}-\mathrm{H}_{2}\right)$ \\
\hline & & $1433(w)$ & $\delta\left(\mathrm{C}-\mathrm{H}_{2}\right)$ and $\delta(\mathrm{O}-\mathrm{H})$ \\
\hline & $1415(\mathrm{~m})$ & & $\delta\left(\mathrm{C}-\mathrm{H}_{2}\right)$ \\
\hline \multirow[t]{4}{*}{$1373(\mathrm{~m})$} & $1369(\mathrm{~m})$ & $1367(\mathrm{~m})$ & $\delta\left(\mathrm{C}-\mathrm{H}_{2}\right)$ \\
\hline & $1309(w)$ & & $v(\mathrm{C}-\mathrm{N})$ and $\delta(\mathrm{N}-\mathrm{H})$ and $\delta(\mathrm{C}-\mathrm{H})$ \\
\hline & $1256(\mathrm{~m})$ & & $v(\mathrm{C}-\mathrm{O}-\mathrm{C})$ and $\delta\left(\mathrm{C}-\mathrm{H}_{2}\right)$ \\
\hline & & $1216(s)$ & $v(\mathrm{C}-\mathrm{O})$ acetyl group \\
\hline \multirow[t]{3}{*}{$1224(\mathrm{~m})$} & $1222(\mathrm{~m})$ & & $v(\mathrm{C}-\mathrm{N})$ and $\delta(\mathrm{N}-\mathrm{H})$ \\
\hline & $1163(s)$ & $1163(\mathrm{~m})$ & $v_{\text {as }}(\mathrm{C}-\mathrm{O}-\mathrm{C})$ ester \\
\hline & & $1124(\mathrm{~m})$ & \\
\hline \multirow[t]{2}{*}{$1083(s)$} & $1064(\mathrm{~m})$ & & $v(\mathrm{C}-\mathrm{O}-\mathrm{C})$ urethane \\
\hline & & $1030(s)$ & $\delta(\mathrm{C}-\mathrm{O})$ \\
\hline \multirow[t]{2}{*}{$926(\mathrm{~m})$} & $959(\mathrm{~m})$ & & \\
\hline & & $899(\mathrm{~m})$ & $\delta(\mathrm{C}-\mathrm{H})$ \\
\hline \multirow[t]{2}{*}{$817(\mathrm{~m})$} & $817(w)$ & & $\delta(\mathrm{C}-\mathrm{H})$ aromatic ring \\
\hline & $734(w)$ & $745(\mathrm{~m})$ & $\delta(\mathrm{C}-\mathrm{H})$ aromatic ring \\
\hline
\end{tabular}

br - broad; $m$ - medium; $s$-strong; sld - shoulder; $w$ - weak; as - anti-symmetric; $s$-symmetric; $v$-stretching; $\delta$-deformation.

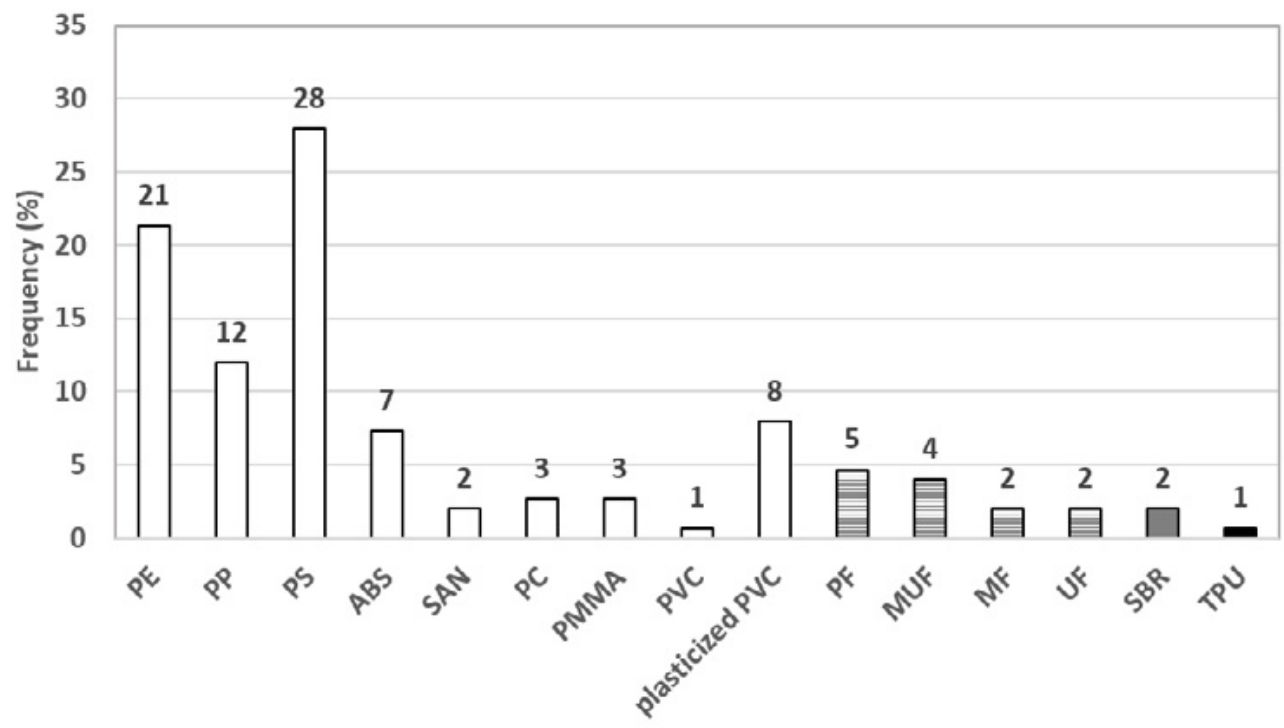

Figure 9. Approximate frequency (\%) of historical plastic objects in the exhibition according to polymer type identified: thermoplastics (white bars), thermosetting (striped bars), elastomers (grey bar) and thermoplastic elastomers (black bar). 


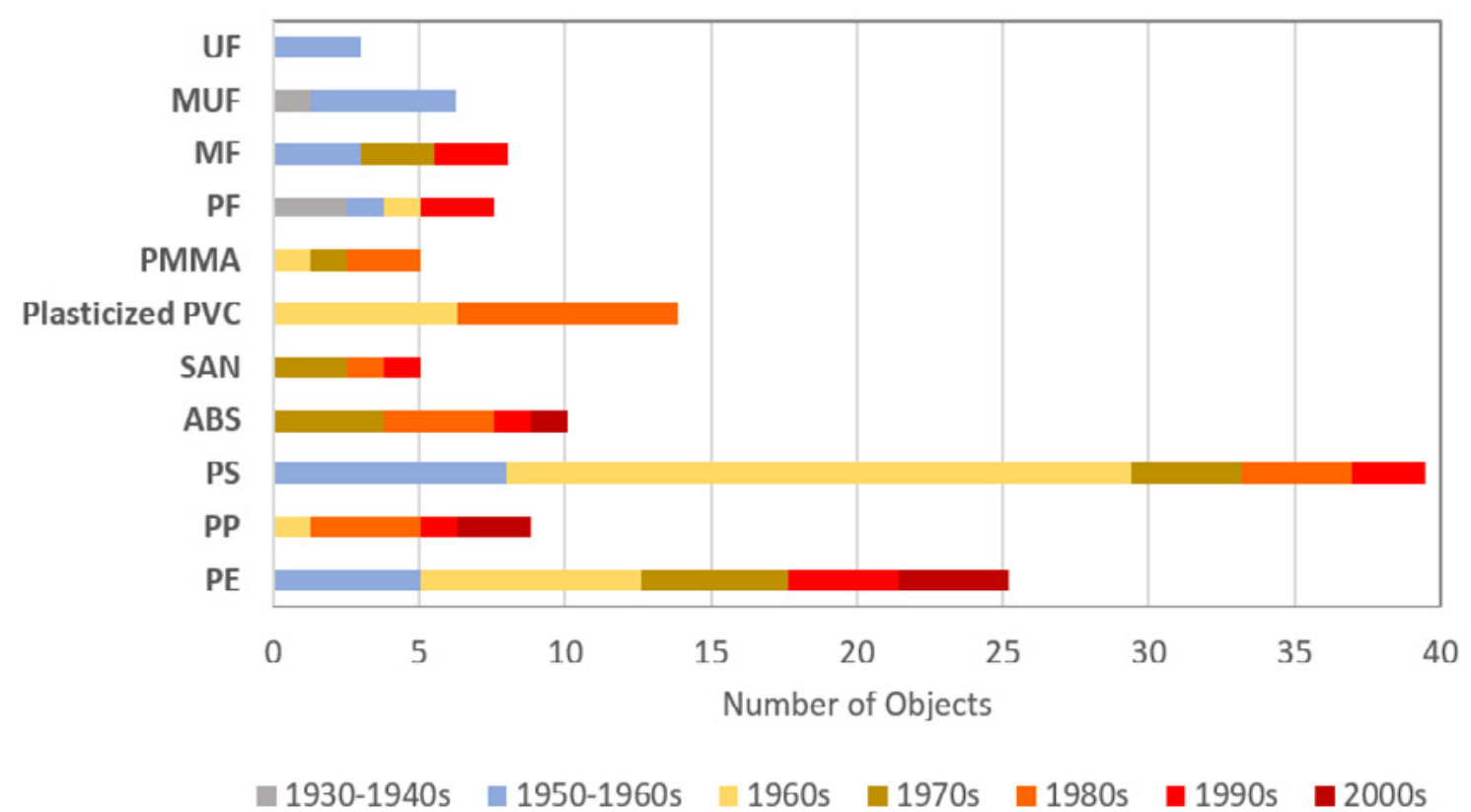

Figure 10. Approximate frequency of the polymer types identified in the selected historical plastic objects for display according to decade of production in Portugal. In this graphic, only the main thermoplastic and thermosetting polymers were included.

\section{Objects preparation for display}

IR spectroscopy has contributed to the preparation of the objects for display as cleaning protocols were established according to their safety and efficiency in relation to the identified plastics. In addition, spectral changes related to molecular degradation were also detected, which alerted to an extra precaution during the cleaning process. This molecular assessment follow a visual examination of the objects (by naked eye and under magnification lenses of $12 \times$ ) that was also helpful to predict possible risks related to the objects interaction to cleaning agents - especially important when yellowing, odour release (especially detected in PE, PP and plasticized PVC historical objects) and brittleness was noticed.

In general, most of the objects showed dust and a combination of loose and fixed particles, allowing the use of blowing clean air and vacuum cleaners, followed by spectacle and/or microfibre cloths (or cotton swabs if necessary, in more detailed surfaces) with distilled water. Dry cleaning methods were avoided as scratches could be induced on both thermoplastic and thermosetting materials [55-56]. For the several dozen objects showing a combination of oily and waxy soil (such as grease and fingerprints), the use of a neutral $\mathrm{pH}$ detergent ( $1 \%$ in distilled water) with microfibre cloth was applied, followed by a rinse with distilled water. For the transparent and/or pristine and shiny objects showing oily or waxy soil, and identified as PS, ABS, SAN or PC, a mixture of ethanol and distilled water $(50 / 50$ or $30 / 70)$ was chosen instead of the detergent solution in order to minimize the number of rubs (imposed in the rinse) and to reduce the risk of surface abrasion (possibly leading to a loss of transparency). This procedure proved to be more effective in the removal of soil (less rubs and more homogenous drying process), and the mixture minimized the risks of solely using ethanol. The same procedure was selected for both plasticized PVC and SBR objects as according to [56-57] no evidences of additives extraction were observed. Nevertheless, this method was not applied in most of the PE and PP historical objects (especially the ones dated up to the 1980s) as signs of advanced degradation such as colour fading, slight acid odour release and frailty were noticed; and therefore, a high polarity and susceptibility to organic solvents could be predicted. For the transparent objects identified as PMMA, the use of the detergent solution was also preferred in relation to ethanol as this solvent could induce environmental stress. In the case of the thermosetting objects, the ones showing matte surfaces proved to be highly susceptible to abrasion; therefore, the exclusive use of distilled water with microfibre cloths was preferable, also to minimize the possible penetration of more aggressive solvents into the porous surface of the object. In some cases, the removal of old adhesives (mostly "all purpose" or "super glue" adhesives) or residues of adhesive tapes was also necessary and for that, IR spectroscopy contributed to the selection of safe and efficient solvents/procedures for their removal.

Regarding storage, the entire set of objects (not on display) has been kept in high density polyethylene (HDPE) stackable plastic boxes (of food grade quality) with PE foam sheets to minimize the impact during handling. The objects have been gathered according to plastic types with the attempt to minimize contaminations caused by the releasing of volatiles. Then, all boxes were covered by a polyester transparent film in order to avoid the deposition of dust. For the objects 
identified as polyurethane (foam and elastomers), SBR and plasticized PVC, a silicone-coated polyester film was put into contact with the object (as an intermediate layer) since the formation of degradation products and the migration of plasticizers might promote adhesion. This measure was also adopted in display (under the objects and without being visible to the visitors). All these actions are temporary as these objects are not part of the museum collection and procedures for their incorporation are still being analysed.

\section{Conclusions}

This pioneering study in Portugal followed a multi and interdisciplinary approach that was crucial for the writing of the history of the Portuguese plastics industry as well as for the decision-making process regarding conservation and restoration procedures. The gathered collection is expected to be maintained in the Museu de Leiria, and now that plastics are identified, the awareness concerning their general labile stability was raised and adequate conservation methodologies for their storage and daily care are being planned.

A contribution to the history of the Portuguese Plastics Industry is told in the exhibition, Plasticidade - Uma História dos Plásticos em Portugal, based on different methodologies from different fields of expertise such as history, conservation and museology. Throughout different sources of information like company's archives, interviews to plastics industry workers and objects, a corpus of knowledge was created aiming at a more comprehensive history of plastic materials. Also, the information collected from the industrialists and workers memories was confronted with the material knowledge brought by the historical objects; and even though the memories were often imprecise and sometimes the company's owners did not know exactly the materials used in the past, this study helped to complement and to validate those memories with the material data collected by infrared spectroscopy.

According to the IR spectroscopy analysis and the information collected by the interviewees, is also possible to indicate that there does not seem to have been a significant delay of Portugal in relation to foreign countries. As constantly mentioned by all former workers of the national plastics industry, novel plastics were quickly introduced in the country trade channels, possibly due to the good commercial network that was being established at that time and the trips abroad by Portuguese industrialists in the context of international fairs.

The plastic objects analysed in this study and those which we touch everyday illustrate complex scientific, technological, socio-economic, industrial and cultural relationships, meanings and values. The carried-out analysis shows how conservation contributes to the preservation of such heritage but also to their knowledge and understanding in the contemporary world.

\section{Acknowledgements}

This work was supported by the funded research project, The Triumph of Bakelite - Contributions to a History of Plastics in Portugal [PTDC/IVCHFC/5174/2014], and by the Associate Laboratory for Green Chemistry - LAQV which is financed by national funds from FCT/MCTES (UID/ QUI/50006/2019). The authors are also grateful to the Municipality of Leiria for funding the exhibition, Plasticidade - Uma História dos Plásticos em Portugal, and to all private collectors, museums, institutions and industries for the loan of objects.

\section{REFERENCES}

1. Lushington, R., Plastics and You. Pan Piper Science Series EP132. A fascinating account of the importance of plastics in the modern world, Pan Books LTD, London (1967).

2. Callapez, M. E., Os plásticos em Portugal: a origem da indústria transformadora, Editorial Estampa, Lisboa (2000).

3. Callapez, M. E., História do PVC em Portugal: Cires - Um Caso de Sucesso, Escolar Editora, Lisboa (2010).

4. Shashoua Y., Conservation of Plastics - materials science, degradation and preservation, Elsevier, Reprinted, Oxford (2009).

5. Lavédrine, B.; Fournier, A.; Martin, G. (eds.), POPART: Preservation of Plastic Artefacts in Museum Collections, Comité Des Travaux Historiques Et Scientifiques (CTHS), Paris (2012).

6. Shashoua, Y., 'Conservation of Plastics: is it possible today?', in Plastics: Looking at the Future, Learning from the Past, eds.

B. Keneghan and L. Egan, Archetype Publications, London (2009) 12-19.

7. van Oosten, T.; Learner, T., 'Identification and characterisation of plastic artefacts. Introduction', in POPART: Preservation of Plastic Artefacts in Museum Collections, eds. B. Lavédrine, A. Fournier, G. Martin, Comité Des Travaux Historiques Et Scientifiques (CTHS), Paris (2012) 29-36.

8. Picollo, M.; Bartolozzi, G.; Cucci, C.; Galeotti, M.; Marchiafava, V.; Pizzo, B., 'Comparative Study of Fourier Transform Infrared Spectroscopy in Transmission, Attenuated Total Reflection, and Total Reflection Modes for the Analysis of Plastics in the Cultural Heritage Field', Applied spectroscopy 68(4) (2014) 389-397, https://doi.org/10.1366/13-07199.

9. Lazzari, M.; Ledo-Suárez, A.; López, T.; Scalarone, D.; LópezQuintela, M. A., 'Plastic matters: an analytical procedure to evaluate the degradability of contemporary works of art', Analytical and Bioanalytical Chemistry 399(9) (2011) 2939-2948, https://doi.org/10.1007/s00216-011-4664-5.

10. Toja, F.; Saviello, D.; Nevin, A.; Comelli, D.; Lazzari, M.; Levi, M.; Toniolo, L., 'The degradation of poly (vinyl acetate) as a material for design objects: A multi-analytical study of the effect of dibutyl phthalate plasticizer. Part 1', Polymer Degradation and Stability 97(11) (2012) 2441-2448. https://doi. org/10.1016/j.polymdegradstab.2012.07.018.

11. Williams, R. S., 'On-Site Non-Destructive MID-IR Spectroscopy of Plastics in Museum Objects Using a Portable Ftir Spectrometer with Fiber Optic Probe', MRS Proceedings 462 (1996) 25-30, https://doi.org/10.1557/PROC-462-25. 
12. Saviello, D.; Toniolo, L.; Goidanich, S.; Casadio, F., 'Noninvasive identification of plastic materials in museum collections with portable FTIR reflectance spectroscopy: Reference database and practical applications', Microchemical Journal 124 (2016) 868-877, https://doi.org/10.1016/j. microc.2015.07.016.

13. Asensio, R. C.; Moya, M. S. A.; de la Roja, J. M.; Gómez, M., 'Analytical characterization of polymers used in conservation and restoration by ATR-FTIR spectroscopy'. Analytical and Bioanalytical Chemistry 395(7), (2009) 2081-2096, https://doi. org/10.1007/s00216-009-3201-2.

14. Noda, I.; Dowrey, A.E.; Haynes, J.L.; Marcott, C., 'Group frequency assignments for major infrared bands observed in common synthetic polymers', in Physical Properties of Polymers Handbook, ed. J.E. Mark, Springer Science +Business Media, LLC, New York (2007) 395-406.

15. Callapez, M. E., 'Plásticos na sociedade portuguesa rural', Revista Brasileira de História da Ciência 3(2) (2010) 200-210, https://www.sbhc.org.br/revistahistoria/view?ID_REVISTA_ HISTORIA $=8$ (accessed 2020-1-31).

16. Matos, A., 'Zeitgeist- O espírito do tempo: António Garcia, Design e Arquitectura nas décadas de 50-70 do século XX. Depois da obra, o futuro', Master dissertation, Universidade de Lisboa, Lisboa (2006).

17. Almeida, V., 'O Design em Portugal, um Tempo e um Modo. A institucionalização do Design Português entre 1959 e 1974', $\mathrm{PhD}$ dissertation, Universidade de Lisboa, Lisboa (2009).

18. Pedroso, G., 'Mudança: O Mobiliário Português da Manufactura ao Processo Industrial', Convergências 12(3) (2009), http://convergencias.esart.ipcb.pt/?p=article\&id=43 (accessed 2020-1-31).

19. Coelho, J. D., Génese e Expansão da Indústria de Plásticos no concelho de Leiria, Câmara Municipal de Leiria, Leiria (2001).

20. Gomes, N., Indústria Portuguesa de moldes para plásticos. Contributos para a sua história, Edição de autor (2015).

21. CETEL - Centro de Estudos Técnico-Económicos, Plásticos: revista da indústria de matérias plásticas 23 (1974).

22. Willbourn, A. H., 'O futuro dos termoplásticos nos países de economia de mercado', Plásticos: revista da indústria de matérias plásticas 27 (1978).

23. Lains, P.; Miranda, S.M.; Costa, L.F., História económica de Portugal, 1143-2010, A Esfera dos Livros, Lisboa (2011).

24. Bhutto, A. A.; Vesely, D.; Gabrys, B. J., 'Miscibility and interactions in polystyrene and sodium sulfonated polystyrene with poly (vinyl methyl ether) PVME blends. Part II. FTIR', Polymer 44(21) (2003) 6627-6631, https://doi. org/10.1016/j.polymer.2003.08.005.

25. Gulmine, J. V.; Janissek, P. R.; Heise, H. M.; Akcelrud, L., 'Polyethylene characterization by FTIR', Polymer Testing 21(5) (2002) 557-563, https://doi.org/10.1016/S0142-9418(01)00124-6.

26. Budevska, B. O.; Manning, C. J.; Griffiths, P. R.; Roginski, R. T., 'Step-scan Fourier transform infrared study on the effect of dynamic strain on isotactic polypropylene', Applied spectroscopy 47(11) (1993) 1843-1851, https://doi. org/10.1366/0003702934065920.

27. Părpăriţă, E.; Darie, R. N.; Popescu, C. M.; Uddin, M. A.; Vasile, C., 'Structure-morphology-mechanical properties relationship of some polypropylene/lignocellulosic composites', Materials \& Design (1980-2015) 56 (2014) 763-772, https://doi.org/10.1016/j.matdes.2013.12.033.

28. Feng, Y.; Wang, B.; Wang, F.; Zhao, Y.; Liu, C.; Chen, J.; Shen, C., 'Thermal degradation mechanism and kinetics of polycarbonate/silica nanocomposites', Polymer degradation and stability 107 (2014) 129-138, https://doi.org/10.1016/j. polymdegradstab.2014.05.012.

29. Huang, X.; Ouyang, X.; Ning, F.; Wang, J., 'Mechanistic study on flame retardance of polycarbonate with a small amount of potassium perfluorobutane sulfonate by TGA-FTIR/XPS, Polymer degradation and stability 91(3) (2006) 606-613, https:// doi.org/10.1016/j.polymdegradstab.2005.02.028.

30. Song, L.; He, Q.; Hu, Y.; Chen, H; Liu, L., 'Study on thermal degradation and combustion behaviors of PC/POSS hybrids', Polymer Degradation and Stability 93(3) (2008) 627-639, https:// doi.org/10.1016/j.polymdegradstab.2008.01.014.

31. Asensio, R. C.; Moya, M. S. A.; de la Roja, J. M.; Gómez, M., 'Analytical characterization of polymers used in conservation and restoration by ATR-FTIR spectroscopy', Analytical and bioanalytical chemistry 395(7) (2009) 2081-2096, https://doi. org/10.1007/s00216-009-3201-2.

32. Ramesh, S.; Leen, K. H.; Kumutha, K.; Arof, A. K., 'FTIR studies of PVC/PMMA blend based polymer electrolytes', Spectrochimica Acta Part A: Molecular and Biomolecular Spectroscopy 66(4-5) (2007) 1237-1242, https://doi.org/10.1016/j. saa.2006.06.012.

33. Tabb, D. L.; Koenig, J. L., 'Fourier transform infrared study of plasticized and unplasticized poly(vinyl chloride)', Macromolecules 8(6), (1975) 929-934, https://doi.org/10.1021/ ma60048a043.

34. Theodorou, M.; Jasse, B., 'Fourier transform infrared study of conformational changes in plasticized poly (vinyl chloride)', Journal of Polymer Science: Polymer Physics Edition 21(11) (1983) 2263-2274, https://doi.org/10.1002/pol.1983.180211104.

35. Beltran, M.; Marcilla, A., 'Fourier transform infrared spectroscopy applied to the study of PVC decomposition', European polymer journal 33(7) (1997) 1135-1142, https://doi. org/10.1016/S0014-3057(97)00001-3.

36. Noda, I.; Dowrey, A.E.; Haynes, J.L.; Marcott, C., 'Group frequency assignments for major infrared bands observed in common synthetic polymers', in Physical Properties of Polymers Handbook, ed. J. E. Mark, Springer Science + Business Media, LLC, New York (2007) 395-406.

37. Kim, S.; Kim, H. J., 'Study of miscibility of melamineformaldehyde resin and poly (vinyl acetate) blends for use as adhesives in engineered flooring', Journal of adhesion science and technology 20(2-3) (2006) 209-219, https://doi. org/10.1163/156856106775897739.

38. Wang, D.; Zhang, X.; Luo, S.; Li, S., 'Preparation and property analysis of melamine formaldehyde foam', Advances in Materials Physics and Chemistry 2(4) (2012) 63-67, https://doi. org/10.4236/ampc.2012.24Bo18.

39. Mircescu, N. E.; Oltean, M.; Chiş, V.; Leopold, N., 'FTIR, FT-Raman, SERS and DFT study on melamine', Vibrational Spectroscopy 62 (2012) 165-171, https://doi.org/10.1016/j. vibspec.2012.04.008.

40. Samaržija-Jovanović, S.; Jovanović, V.; Konstantinović, S.; Marković, G.; Marinović-Cincović, M., 'Thermal behavior of modified urea-formaldehyde resins', Journal of thermal analysis and calorimetry 104(3) (2011) 1159-1166, https://doi.org/10.1007/ s10973-010-1143-8. 
41. Poljansek, I.; Krajnc, M., 'Characterization of phenolformaldehyde prepolymer resins by in line FT-IR spectroscopy', Acta Chimica Slovenica 52(3) (2005) 238-244, http://acta-arhiv. chem-soc.si/52/52-3-238.pdf (accessed 2020-1-31).

42. Zhao, Y.; Yan, N.; Feng, M. W., 'Thermal degradation characteristics of phenol-formaldehyde resins derived from beetle infested pine barks', Thermochimica Acta 555 (2013) 46-52, https://doi.org/10.1016/j.tca.2012.12.002.

43. Chen, Y.; Chen, Z.; Xiao, S.; Liu, H., 'A novel thermal degradation mechanism of phenol-formaldehyde type resins', Thermochimica Acta 476(1-2) (2008) 39-43, https://doi. org/10.1016/j.tca.2008.04.013.

44. Popović, M.; Budinski-Simendic, J.; Miljkovic, J.; Pavlicevic, J.; Ristic, I., 'Curing characteristics of low emission ureaformaldehyde adhesive in the presence of wood', Wood Research 56(4) (2011) 589-600, https://pdfs.semanticscholar. org/8a2f/cbf3aaea2979bea90144bbfe36f997ef16b6.pdf (accessed 2020-1-31).

45. Li, Y.; Zhou, T.; Chen, Z.; Hui, J.; Li, L.; Zhang, A., 'Nonisothermal crystallization process of polyoxymethylene studied by two-dimensional correlation infrared spectroscopy', Polymer 52(9) (2011) 2059-2069, https://doi. org/10.1016/j.polymer.2011.03.007.

46. Busca, G.; Lamotte, J.; Lavalley, J. C.; Lorenzelli, V., 'FT-IR study of the adsorption and transformation of formaldehyde on oxide surfaces', Journal of the American Chemical Society 109(17) (1987) 5197-5202, https://doi.org/10.1021/ja00251a025.

47. Dannoux, A.; Esnouf, S.; Begue, J.; Amekraz, B.; Moulin, C., 'Degradation kinetics of poly (ether-urethane) Estane ${ }^{\circledR}$ induced by electron irradiation', Nuclear Instruments and Methods in Physics Research Section B: Beam Interactions with Materials and Atoms 236(1-4) (2005) 488-494, https://doi. org/10.1016/j.nimb.2005.04.025.

48. Yilgör, I.; Yilgör, E.; Wilkes, G. L., 'Critical parameters in designing segmented polyurethanes and their effect on morphology and properties: A comprehensive review', Polymer 58 (2015) A1-A36, https://doi.org/10.1016/j.polymer.2014.12.014.

49. Li, C.; Liu, J.; Li, J.; Shen, F.; Huang, Q.; Xu, H., 'Studies of 4,4-diphenylmethane diisocyanate (MDI)/1,4-butanediol (BDO) based TPUs by in situ and moving-window two-dimensional correlation infrared spectroscopy: Understanding of multiple DSC endotherms from intermolecular interactions and motions level', Polymer 53(23) (2012) 5423-5435, https://doi.org/10.1016/j. polymer.2012.09.030.

50. Priester, R. D.; Mcclusky, J. V.; O’Neill, R. E.; Turner, R. B.; Harthcock, M.; Davis, B. L., 'FT-IR-A Probe into the Reaction Kinetics and Morphology Development of Urethane Foams', Journal of Cellular Plastics 26(4) (1990) 346-367, https://doi. org/10.1177/0021955X9002600405.

51. Guignot, C.; Betz, N.; Legendre, B.; Le Moel, A.; Yagoubi, N., 'Degradation of segmented poly(etherurethane) Tecoflex ${ }^{\circledR}$ induced by electron beam irradiation: Characterization and evaluation', Nuclear Instruments and Methods in Physics Research Section B Beam Interactions with Materials and Atoms 185(1) (2001) 100-107, https://doi.org/10.1016/S0168-583X(01)00850-3.

52. Barud, H. S.; de Araújo Júnior, A. M.; Santos, D. B.; de Assunção, R. M.; Meireles, C. S.; Cerqueira, D. A.; Filho, G. R.; Ribeiro, C. A.; Messaddeq, Y.; Ribeiro, S. J., 'Thermal behavior of cellulose acetate produced from homogeneous acetylation of bacterial cellulose', Thermochimica Acta 471(1-2) (2008) 6169, https://doi.org/10.1016/j.tca.2008.02.009.

53. Lucena, M. C. C.; de Alencar, A. E. V.; Mazzeto, S. E.; de A Soares, S., 'The effect of additives on the thermal degradation of cellulose acetate', Polymer Degradation and Stability 80(1) (2003) 149-155, https://doi.org/10.1016/S0141-3910(02)00396-8.

54. Murphy, J., (ed.), Additives for plastics handbook, th ed., Elsevier, Oxford (2001).

55. Shashoua, Y.; Segel, K.; van Oosten, T.; Lagana, A.; Keneghan, B.; Barabant, G.; Bollard, C.; Kuperholc, S., 'Wiping away the dirt-a safe option for plastics?', in ICOM-CC Lisbon 2011: preprints 19-23 September, Lisboa (2011).

56. Shashoua, Y.; Segel, K., 'Cleaning plastics in museums', Meddelelser om konservering 2 (2013) 3-12, https://docplayer. dk/19591938-Meddelelser-om-konservering.html (accessed 2020-1-31).

57. Muñoz, C. M.; Egsgaard, H.; Landaluze, J. S.; Dietz, C., 'A model approach for finding cleaning solutions for plasticized poly (vinyl chloride) surfaces of collections objects', Journal of the American Institute for Conservation 53(4) (2014), 236-251, https://doi.org/10.1179/0197136014Z.00000000040.

RECEIVED: 2019.6.17

REVISED: 2019.11.18

ACCEPTED: 2020.1.6

ONLINE: 2020.5.13

\section{(c) (1)(3)}

This work is licensed under the Creative Commons Attribution-NonCommercial-NoDerivatives 4.0 International License. To view a copy of this license, visit

http://creativecommons.org/licenses/by-nc-nd/4.o/deed.en. 